\title{
Yerli ve Yabancı Turistlerin Her Şey Dahil Sistemini Tercih Nedenleri ve Memnuniyet Düzeyleri: Antalya Örneği ${ }^{1}$
}

\author{
Mustafa BOZ* Buket BULUK EŞiTTí**
}

ÖZET

Özellikle Antalya ilinde yer alan konaklama işletmelerinde yaygın olarak kullanılan her şey dahil sistemi, yerli ve yabanc1 turistlerin bu bölgeyi tercih etmelerinde önemli bir etkiye sahiptir. $\mathrm{Bu}$ anlamda bu çalışmanın temel amacı, Antalya'yı ziyaret eden ve her şey dahil sistemi ile konaklayan yerli ve yabancı turistlerin her şey dahil sistemini tercih nedenlerini, her şey dahil sistemini tercih ederken önem verdikleri konuları ve bu sistemden memnuniyet düzeylerini tespit edebilmektir. Bu amaçla çalışmanın saha araştırması, tatillerini her şey dahil paket tur satın alarak Antalya'da geçiren yerli ve yabancı turistler ile 1 Nisan-30 Mayıs 2018 tarihleri arasında kolayda örnekleme yöntemi ile yüz yüze anket uygulanarak gerçekleştirilmiştir. Elde edilen veriler, her şey dahil paket tur alırken turistler için en önem verdikleri konulardan "otelin sosyal medyadaki genel değerlendirmesi", "aile ve arkadaş tavsiyeleri" ve "tatilin güvenli olması" unsurlarının ilk üç sırada yer aldığı görülmüştür. Turistlerin memnun kaldıkları konular arasında ise ilk üç sırada "fiyat", "yiyecek ve içeceklerin çeşitliliği”" ve "yiyecek ve içeceklerin kalitesi" unsurlarının yer aldığı tespit edilmiştir. Çalışma sonucunda, her şey dahil sistemde yer alan konaklama işletmeleri yöneticilerine stratejik fikirler sağlayabileceği düşüncesinden hareketle birtakım önerilerde bulunulmuştur.

\section{Reasons of Domestic and Foreign Tourists' Preferences of All-Inclusive System and Satisfaction Levels: Antalya Case}

ABSTRACT

All-inclusive system, which is widely used especially in the accommodation businesses in Antalya province, has an important effect on the local and foreign tourists preferring this region. In this sense, the main purpose of this study is to determine the reasons why local and foreign tourists who visit Antalya and stay with the all-inclusive system prefer this system, the issues they care about when choosing the all-inclusive system, and their satisfaction level with this system. For this purpose, the field research of the study was carried out by applying a face-toface questionnaire with the easy sampling method between April 1 and May 30, 2018 with local and foreign tourists who spend their holidays in Antalya by purchasing an all-inclusive package tour. The data obtained showed that "the general evaluation of the hotel on social media", "family and friend recommendations" and "the safety of the holiday", which are among the most important issues for tourists while taking an all-inclusive package tour, are in the top three. It was seen that among the top three issues that tourists are satisfied with are "price", "variety of food and beverages" and "quality of food and beverages". As a result of the study, some suggestions were made based on the idea that it can provide strategic ideas to the managers of the accommodation businesses in the all-inclusive system.
Araştırma Makalesi

Geliş: 05.12.2020

Kabul: 26.12.2020

Anahtar Kelimeler:

Her Şey Dahil Sistemi,

Konaklama İşletmeleri,

Paket Tur,

Turist Memnuniyeti,

Turist Tercihleri.

Research Article

Received: 05.12.2020

Accepted: 26.12 .2020

Keywords:

All Inclusive System,

Accomodation

Businesses,

Package Tour,

Tourist Satisfaction,

Tourist Preferences.

${ }^{1} \mathrm{Bu}$ çalışma, Çanakkale Onsekiz Mart Üniversitesi Bilimsel Araştırma Projeleri Koordinasyon Birimince Desteklenmiştir. Proje No:1240.

* Prof. Dr., Çanakkale Onsekiz Mart Üniversitesi, Konaklama İşletmeciliği Anabilim Dalı, m.b.istanbul@gmail.com, ORCID ID: https://orcid.org/0000-0002-9823-4117

${ }^{* *}$ Arş. Gör. Dr., Çanakkale Onsekiz Mart Üniversitesi, Konaklama İşletmeciliği Anabilim Dalı, bulukbuket@comu.edu.tr, ORCID ID: https://orcid.org/0000-0001-5646-6166 


\section{GíRiș}

Turizm sektörü, en hızlı gelişme gösteren ve sosyo-ekonomik olgu olma özelliğini sürdüren bir sektördür. Günümüzde turizm, gelişmiş ve gelişmekte olan birçok ülke için en önemli sektörlerden birisi haline gelmiştir. Zira turizmin geliştiği bir ekonomide, bunun etkileri hem ekonomik hem de sosyal alanlarda kendini hissettirmektedir. Gelişen turizm sektörü, bir ülkenin ödemeler dengesinin düzelmesinde, gelir yaratılmasında dolayısıyla ülke döviz gelirlerinin arttırılmasında, bağlantılı olduğu diğer birçok sektörün (inşaat, yeme-içme, eğlence, taşımacılık vb.) hareketlenmesinin sağlanmasında, altyapı ve üstyapı yatırımlarının arttırılmasında ve en önemlisi istihdam olanaklarının yaratılarak işsizlik probleminin yükünün azaltılmasında önemli etkilere sahiptir. Türkiye için de turizm sektörü ekonomik kalkınmada kilit bir rol oynamakta olup, döviz kaynağı ve istihdam yaratmada ulusal bir önceliğe sahiptir.

İkinci dünya savaşının ardından 1950'lerde ivme kazanmaya başlayan uluslararası turizm hareketleri, 1970 ve 1980’li yıllarda deniz-kum-güneş üçlüsüne dayalı, insanların kitle halinde hareket ettiği, turist davranışlarının pasif olduğu, standartlaştırılmış paket turlarla geleneksel kitle turizmi olarak gelişme göstermiştir (Cojocariu, 2015: 960). 1970'li y1llar itibariyle turizm endüstrisine yönelik yaşanan büyük çaplı gelişmelerdeki en önemli faktör paket turlardır. Paket turlar, ortaya ilk çıktığı dönemlerde belirli toplulukların belirli amaçlar kapsamında yararlandıkları seyahatlerden oluşmaktayken, sonraki dönemlerde "hızlı" ve "ucuz" seyahatler gerçekleştirmek isteyen gruplara ulaşmasıyla birlikte “yaygınlık” kazanmıştır (Gürkan, 2002: 52). Kitle turizminin yaygınlaştı̆ğ 1990’lı yıllarda paket turların içerisine uçak biletlerinin, konaklamanın (oda-kahvaltı, yarım ya da tam pansiyon), rehberlik hizmetlerinin ve havaalanı transferlerinin dâhil edilmesiyle yerel seyahat acenteleri veya aracı ve dağıtıcı kuruluşlarla satışlarını yapan tur operatörleri, zamanla paket programlarına değişik bir boyut kazandırmışlardır. Bu boyut da, konaklama işletmelerinin sundukları oda-kahvaltı, yarım veya tam pansiyon uygulaması yerine her şey dahil konaklamalara ağırlık vermeleridir (Gökdeniz, vd., 2000: 290). Paket tur içerisinde yer alan "her şey dahil sistemi”nin ilk uygulaması, çevre koşullarının yetersizliği ve aktivite eksiklikleri sebebiyle, Karayipler'de çevresi yüksek duvar ve teller aracılığıyla koruma altında olan geniş çaplı otellerde, lüks şato ve saraylarda gerçekleşmiştir. Daha çok İngiliz tur operatörleri tarafından gelir seviyesi yüksek kişilere yönelik paket olarak hazırlanan bu turlar, daha sonra hızla yayılmış ve Akdeniz'e kıyı ülkelerle birlikte Türkiye'de de uygulanmaya başlanmıştır (Yürik, 2002: 292).

Türkiye gerek tarihi, kültürel, doğal güzellikleri ile gerekse de gelişmiş üst ve altyapı yatırımları ve yetişmiş insan kaynağı ile büyük bir turizm potansiyeline sahiptir. Geçmiş yıllarda Türkiye, daha çok 
turist sayısını hedefleyerek, deniz-kum-güneş olarak da adlandırılan kitle turizmine odaklanmıştır. Bunun sonucunda Türkiye'de, paket turlar ve paket turların ileri aşaması olarak her şey dahil paket tur sistemi gittikçe yaygınlaşmıştır.

Her şey dahil sistem; daha önce uygulamadaki "oda-kahvaltı", "yarım pansiyon" ve "tam pansiyon" konaklama türlerinden ziyade; kahvaltı, öğle-akşam yemekleri, ara öğünlerde verilen yemekler, gece yemekleri, yerli-yabancı içkiler, sıcak soğuk içecekler, animasyonlar, spor aktiviteleri ve müşterilerin ihtiyaç duyabilecekleri diğer tüm aktivite ve hizmetlerin fiyata dahil olduğu bir sistemdir (Otar, 2008). Müşteriler bu sistemde, tatil ücretlerini peşin ödemekte ve bu sayede tatilleri esnasında ödeme yapma kaygısı taşımadan, ekstra harcamalardan uzak bir tatil geçirme imkânı bulmaktadır. Bu anlamda bu çalışmanın amacı, Antalya'yı ziyaret eden ve her şey dahil sistemi ile konaklayan yerli ve yabancı turistlerin her şey dahil sistemini tercih nedenlerini, her şey dahil sistemini tercih ederken önem verdikleri konuları ve bu sistemden memnuniyet düzeylerini tespit edebilmektir.

\section{LITTERATÜR İNCELEMESI}

\section{Her Şey Dahil Sistemi Kavramı}

"Her şey dahil sistemi”, "paket tur" çeşitleri arasında yer almaktadır. "Paket tur", bir seyahatin ayrı ayrı parçaları olan "ulaştırma", "konaklama", "yeme-içme", "eğlence" gibi tamamının veya bir kısmının birleştirilmesiyle turistik tüketicilere "tek bir ürün” ve "fiyat" şeklinde satılması olayını kapsayan faaliyetler bütününü ifade etmektedir (Çevirgen ve Üngüren, 2009). "Her şey dahil tatil”" kavramı ise; "uçak bileti”, "havaalanı transferleri”, "konaklama”, “yiyecek ve içecekler”, “tüm tesis ve donanımların kullanımı" unsurlarını kapsayan ve ücretinin önceden ödenmesini gerektiren tatilleri belirtmektedir (Özdemir, 2001). Her şey dahil sistemi, günümüzde yerli içecekler dahil her şey dahil, içeceklerin belirli saatler arasında ve belirli yerlerde servis edildiği her şey dahil, ekstra her şey dahil, ultra her şey dahil, maksimum her şey dahil gibi farklı uygulamaları içermektedir.

Paket turların ilk uygulamalarına, 1930'lu yılların başında İngiltere'deki tatil kamplarında rastlanmaktadır. Ancak, bu dönemde uygulamada olan sistem kapsamında içecekler ve diğer hizmetler için ödeme yapıldı̆̆ından paket turlar, “her şey dahil”" şeklinde ifade edilmemektedir. 1950'lerde Fransız bir yatırımcının İspanyol adası Mayorka sahilinde bir tatil kampı kurduğu ve yatırımcının, İspanyol devleti tarafından "yiyecek", "konaklama" ve "diğer faaliyetler"e yönelik önceden belirlenmiş tek bir fiyatı uygulamakla yükümlü tutulduğu belirtilmiştir. Yine, 1950’lerle birlikte Club Mediterranean'ın "Club Tatil” adı altında her şey dahil sistemini dünya genelinde yer alan diğer tatil köylerinde uygulamaya başladığı ve her şey dahil sisteminin yayılmasını sağladığı ifade edilmiştir. Club Mediterranean tarafından yaygınlaşmasının sağlanmaya başlandığı her şey dahil sistemi, bütün 
konaklama hizmetleri için önceden belirlenmiş tek bir fiyat sisteminin uygulamaya konması, etrafının yüksek duvarlarla ve teller aracılığıyla koruma altına alındığı, doğal çekiciliklerinin haricinde tarihi ve kültürel çekicilikleri olmayan Karayipler destinasyonunda "lüks şato" ve "saray”larda bütün ihtiyaçları karşılanmış bir şekilde tatil yapmayı arzulayan varlıklı turistik tüketicilerin sayılarının artış göstermesiyle büyük gelişmeler kaydetmiştir (Üner vd., 2006).

Zengin turistlere yönelik olarak başlayan her şey dahil tatil konsepti zaman içerisinde şekil değiştirmiştir. Tur operatörleri tarafından bir tatilin, turistlerin kendilerinin düzenleyebileceklerinden "çok daha ekonomik" bir fiyata mal edilmesi ve bunu bir paket şeklinde satmaları (Gürkan, 2002) ile tatile gidemeyen "orta" ve "az gelirli" turistik tüketicilerin kitle turizminin ucuz tatil imkanlarından yararlanmalarına firsat vermiş, yıllar içerisinde paket turlara yönelik taleplerinin artmasını sağlamıştır (Alaeddinoğlu ve Can, 2007).

\section{Her Şey Dahil Sistemini Tercih Nedenleri}

Turistik tüketicilerin paket turları tercih etme nedenleri arasında "güvence sunması", "garantili düzenlemeler”, “faaliyetlere katılma garantisi”, “acentaların deneyim ve bilgisine olan güven”, “tur giderlerinin önceden bilinmesi”, “daha uygun fiyatlı tatil olanakları”, "zaman tasarrufu sağlaması” gibi gerekçeler yer almaktadır (Gürkan, 2002). Her şey dahil sistemin çıkış düşüncesi, turistik tüketicilerin tatilleri boyunca parasal işlemlerini minimuma indirgeyerek parasal konularda karar almak zorunda kalmamaları, para harcamanın ortaya çıkarabileceği sıkıntı ve sorunları ortadan kaldırma düşüncesinden kaynaklanmaktadır (Issa ve Jayawardena, 2003).

Her şey dahil sistemin, gün içindeki çeşitli harcamaları nedeniyle özellikle çocuklu aileler tarafından “ekstra ödemelerden kurtulmak” amacıyla tercih edildiği belirtilmektedir. Demir (2002) yapmış olduğu araştırmada, her şey dahil sisteminin “peşin ödeme rahatlığı” sebebiyle özellikle kalabalık aileler tarafından tercih edildiği tespit edilmiştir. Buna ek olarak, "günlük harcamaları takip etme zorunluluğunun olmaması" ve "istenildiği kadar tüketim yapabilme kolaylığı"nın her şey dahil sisteminin çekiciliğini arttırdığını belirtmiştir. "Her türlü yiyecek ve içeceğin", "rekreasyonel faaliyetlerin", "sportif aktivitelerin" ve buna benzer "diğer maliyetlerin” bütününü kapsayan "sabit ücret”, tatile katılan turistik tüketicileri “detaylarla uğraşmaktan” kurtarmaktadır (Çifçi vd., 2007).

Heung ve Chu'nun 2000 yılında Hong Konglu turistlerle yaptıkları araştırmada, turistlerin her şey dahil sistemini tercih etme nedenleri arasında ilk üç sırada "acentenin ünü" "sözlü iletişim" ve “personel davranışları” olduğu görülmüştür. 
Üngüren ve Cengiz'in 2009 yılında yapmış oldukları çalışmada, ABD'li turistik tüketicilerin \%52'sinin her şey dahil sistemini tercih ettikleri görülmüştür. ABD’li turistlerin bu sistemi seçme nedenleri arasında "sabit ücretin her şeyi içermesinin kolaylık sağlaması" ve "beklenmedik tatil maliyetlerini ortadan kaldırması" olduğu belirlenmiştir. Özetle, her şey dahil sistemin ana fikrinin, "tatil süresince parasal işlemleri en aza indirmek", "para ile ilgili bazı kararları almamak", "para harcamanın oluşturabileceği sıkıntı veya sorunları ortadan kaldırmak” olduğu ifade edilmiştir (Issa ve Jayawardena, 2003: 168).

Her şey dahil sisteminin, seyahat acentaları ve tur operatörleri açısından da pazarlamaya yönelik birtakım kolaylıklar sağlaması nedeniyle talep gördügü belirtilmektedir (Gürkan, 2002). Konaklama işletmeleri tarafından "her şey dahil sistemi”"ne yönelmelerine yönelik en önem arz eden unsur olarak, her şey dahil sisteminin “doluluk oranlarını arttırması”" işaret edilmektedir. Her şey dahil sisteminin konaklama ve ulaştırma işletmeleri açısından tercih edilmesinin diğer nedenleri arasında ise konaklama ve ulaştırma işletmelerinin doluluk oranlarını artırması, bu işletmelere yeni potansiyel pazarlar oluşturması, bu işletmelerin reklam ve tanıtım giderlerini azaltması, bu işletmelerin tanıtımını sağlaması ve bu işletmelerin verimliliğini ve karlılığını artırması gibi faktörler yer almaktadır (Tuncer, 1997: 38). Demir ve Demir'in 2001 yılında gerçekleştirdikleri çalışmada, konaklama işletmeleri tarafından her şey dahil sistemine geçişin doluluk oranlarını arttırdığı sonucuna ulaşılmıştır. Yürik (2002), konaklama işletmelerinin her şey dahil sistemine yönelmelerinin temel nedeninin "ürün ve hizmetlerini daha rahat pazarlayarak doluluk oranlarını arttırmak" olduğunu ifade etmiş ve bu sistemin, "her şeyi hazır bulmak isteyen”, "bunun kolay yolunu tercih eden”, "teknoloji dünyasında var olmaya çalışan" turistik tüketiciler tarafından da "kolay bir şekilde kabullenilmiş bir pazarlama sistemi" olduğu belirtilmiştir.

\section{Her Şey Dahil Sisteminin Yaygınlı̆̆ı}

Dünya genelinde ve Türkiye'de özellikle deniz-kum-güneş turizmine dayalı kıyı bölgelerde her şey dahil paket turlar gittikçe yaygınlaşmaktadır. Yapılan araştırmalarda Kenya'ya giden turistlerin \%87'sinin, İspanya'nın Balear ve Mayorka adalarına giden turistlerin \%85'inin (tourismconcern.org.uk, 2012); ABD'li turistlerin ise \%52'sinin her şey dahil sistemini tercih ettikleri (Üngüren ve Cengiz, 2009) görülmüştür. Ayrıca, Türkiye’ye ve Tunus'a satılan tur paketlerinde her şey dahil turların oranı \%90 iken, Tayland'da bu oran \%28, Yunanistan'da \%62, Kıbrıs'ta \%43, Birleşik Arap Emirlikleri'nde ve İspanya'da \%34, Vietnam'da \%23 olarak kaydedilmiştir (Çelik, 2017). Her şey dahil talep ve arz gittikçe artmaktadır (Anderson, 2012: 318). Dominik Cumhuriyeti, dünyanın en büyük her şey dahil tatil endüstrisiyle Karayipler'in en popüler destinasyonudur (responsibletravel.com, 2013). 
Antalya'ya gelen yabancı turistlerin ise \%85'i paket turları, bunların da \%82'si her şey dahil paket turları kullanmaktadır (Aksu vd., 2008). Ekin Yazım Merkezi Araştırma Birimi'nin 2004'te yaptığı çalışma, her şey dahil sistemin yurtdışı pazarını takiben yurtiçi pazarında da yayıldığını göstermiştir. Her şey dahil sistemi uygulayan tesislerin arzı, artan talebe bağlı olarak büyümektedir. 2011 yılı verilerine göre uluslararası tur operatörü Thomas Cook, sadece Türkiye broşürlerinde 135 her şey dahil tesise yer vermiştir (Johnson, 2011). "Alltours", \%85 oranla en fazla "her şey dahil tur" satan tur operatörüyken TUI ise \%50 oranla en düşük "her şey dahil tur" satan şirket olmuştur. Çalışmanın gerçekleştirildiği altı adet tur operatörünün ortalamasının ise \%69 şeklinde saptandığı görülmüştür. Bu tespit, her şey dahil sisteminin Türkiye turizminin geleceğine yönelik olarak ele alınmasını ve incelenmesini gerektiren bir konuya dönüşmesine yol açmıştır (Resort Turizm ve Seyahat Dergisi, 2004: 16).

\section{Her Şey Dahil Sisteminin Olumlu ve Olumsuz Tarafları}

Her şey dahil sisteminin olumlu ve olumsuz tarafları sıklıkla tartışılan konular arasında yer almaktadır. Bu tartışmaların çoğunlukla "turistler", "konaklama işletmeleri”, "seyahat acentaları", "yöre esnafi" ve "bölge ya da bölge ekonomisine ve topluma katkısı” bağlamlarında değerlendirildiği görülmektedir (Özdemir, 2001).

Her şey dahil sistemi, en başta uygulayıcılar konumundaki konaklama işletmeleri açısından oldukça avantajlı bir pazarlama yaklaşımı olarak değerlendirilmektedir (Barak, 2006). Her şey dahil sisteminin uygulanması ile birlikte geçmiş yıllardaki turizm sezonlarına göre daha uzun sezonlar yaşanmaktadır. Yapılan araştırmalar her şey dahil sisteminin, turizm sezonunun 15 ile 30 günlük bir uzamaya sebep olduğunu göstermiştir (Menekşe, 2005). Ayrıca, yıl içerisindeki bayram tatilleri, yıllık izin vb. gibi zamanların turistik amaçlı olarak kullanıldığı düşünüldüğünde, yıl içerisinde 7-8 aylık bir turizm sezonundan bahsedilebilir. Her şey dahil sistemini uygulayan konaklama işletmelerine, hizmetleri karşılığında seyahat acenteleri ve tur operatörleri tarafından ödenen kısa vadeli yüksek miktarlı ödemeler, konaklama işletmelerinin mali yapılarının geliştirilmesi açısından önemlidir (Üner vd., 2006).

Konaklama işletmelerini tercih edecek konuk sayılarının daha önceden bilinmesi sonucu, özellikle malzeme alımlarında toplu alımları tercih eden konaklama işletmelerinin maliyetleri düşürme anlamında başarılı olmaları da her şey dahil sisteminin işletmeler açısından olumlu katkıları arasındadır. Her şey dahil sisteminin konaklama işletmelerinin maliyetlerini düşürmesi açısından avantajlı olan bir başka olumlu etkisi ise, nitelikli işgören sayılarının azalması ve konaklama işletmeleri için büyük bir maliyet yükü olan işçilik giderlerinin azalmasıdır (Otar, 2008). 
Öte yandan, Türkiye destinasyonunda her şey dahil sistemini uygulamakta olan otellerin toplam cirolarının binde 5-10'unun "reklamasyon" olarak adlandırılan faturalara ödendiği belirtilmektedir. Söz konusu "reklamasyon” ödemeleri irdelendiğinde şikayetlerin çoğunlukla "yiyecek ve içeceklerin nitelik ve niceliğinden", "yiyecek ve içecek servisinin iyi organize olmamasından" ve "hijyenik konulardan" kaynaklı olduğu dikkat çekmektedir. Buradan da anlaşılacağı üzere birtakım "standart"ların oluşturulması zorunludur. "Yıldızlama" ve "belgelendirme" işlemlerinde asıl olan “turizm tesisleri yönetmeliği” ve "konaklama tesisleri genel nitelikleri” göz önüne alındığında, otel işletmeleri açısından birtakım standartların oluşturulduğu ve söz konusu standartların bir bölümünün her şey dahil sistemini "dolaylı" bir şekilde ilgilendiren "yiyecek-içecek", "servis" ve "hijyen kuralları"nı kapsadığı anlaşılmaktadır (Yurtseven, 2004).

Her şey dahil paket turların büyük bölümünde, turist harcamalarının $\% 80$ kadarı, yerel işletmelere ve çalışanlara değil, merkezleri genellikle turist gönderen ülkelerde bulunan hava yollarına, konaklama tesislerine, tur operatörlerine ve diğer uluslararası şirketlere gitmektedir. Buna ilave olarak, yörede kalan gelirin önemli bir bölümü de sızıntı yoluyla tekrar yöreden dışarı çıkmaktadır (UNEPTIE, 2007). Her şey dahil sistem nedeniyle azalan gelirler ve artan sızıntı, bu durumu açıklamaya yardımcı olabilir. Çünkü yabancı turistlere yönelik paket turlar, yabancı tur operatörleri tarafından pazarlanmakta, elde edilen gelirlerin önemli bir bölümü ya ülkeye hiç girmemekte ya da yeniden yurtdışına çıkmaktadır.

Bunun yanında; her şey dahil paket turların yaygınlaşması, Türkiye'ye gelen turist profilini de olumsuz olarak etkilemektedir. Özdemir ve diğerleri (2011: 504) yaptıkları çalışmada her şey dahil sistem ile konaklayan müşteri profilinin genel olarak düşük ve orta gelirli kesimlerden oluştuğunu vurgulayarak önemli bir noktaya dikkat çekmektedirler. Benzer çalışmalar da bu argümanı desteklemektedir. Boz (2004) araştırmasında Antalya'yı ziyaret eden turistlerin \%33'ünün düşük gelir grubundan, \%45'inin orta gelir grubundan oluştuğunu tespit etmişstir. Aksu ve diğerlerinin (2008) araştırmasına göre de Antalya'yı ziyaret eden turistlerin \%34,8'inin yıllık gelirleri 6.000 avrodan az, \%20,1'inin yıllık gelirleri 6.000-12.000 avro arasında ve \%11,4'ünün yıllık gelirleri 12.000-18.000 avro arasındadır.

Kitle turizmini büyük oranda yönlendiren uluslararası tur operatörleri TUI ve Thomas Cook, müşterilerini turlara katılmaları ve her şey dahil tesislerin dışında da zaman harcamaları konusunda teşvik ettiklerini belirtmektedirler. Ancak yine de turistlerin kaldıkları otellerde yiyip içmeleri ve böylece yerel ekonomiye katkılarının son derece kısıtlı kalması nedeniyle, farklı tatil yörelerinde birçok bar ve restoran iş yapamaz duruma düşüp kapanmak zorunda kalmaktadır (Johnson, 2011). 
Bunun yanında, turizm kısa dönemli para kazanmak için ekonomik bir firsat olarak görülmekte, bu anlayış da hizmet kalitesinde bir düşüşe yol açmaktadır. Bu sebeple, yanlış uygulamalar uzun dönemli sürdürülebilir turizm kalkınması için ve ayrıca doğal, kültürel ve tarihi kaynakların korunmasına yönelik tehdit oluşturmaktadır. Buna ilave olarak, hatalı uygulamaların yerel toplum üzerinde de birçok olumsuz etkiye yol açtığı bilinmektedir. Büyük oranda turizme bağımlı olmak, yerel işletmeler ve halk ile uluslararası tur operatörleri arasındaki ilişkilerde büyük bir eşitsizlik anlamına gelmektedir. Tourism Concern Topluluğu (2012), Türkiye'deki otelciler birliklerinden ve belediye başkanlarından, İngiliz tur operatörleri tarafindan otellerini her şey dahil sisteme çevirmek için baskıya maruz kaldıklarını belirten öfke, hayal kırıklığı ve sıkıntı taşıyan raporlar aldıklarını belirtmektedir. Fethiye'de her şey dahil sistemini uygulayan bir otelde yapılan analizde, turist harcamasının sadece \%10’unun bölge ekonomisine ulaştığı, komşu Sarıgerme köyünde bu oranın daha da az olduğu ortaya çıkmıştır. Örneğin, ortalama bir turistin köy dükkânlarında bir günde harcadığı para 1 avro civarındadır (Datar, 2012).

Daha çok belirli müşteri kitlelerine hitap eden her şey dahil tur sistemi; denizi, güneşi, tarihi ve kültürel mekânları ile adeta "dünyanın açık hava müzesi” olan Türkiye bağlamında uygun olmadığına yönelik görüşlerin yoğun olduğu görülmektedir (Barak, 2006). Buna ek olarak, gerçekleştirilen yanlış uygulamaların neticesinde her şey dahil sistemi, Türkiye destinasyonunu ucuz bir pazara dönüştürmektedir. Her şey dahil tur fiyatları azaldıkça sunulan hizmetin kalitesi de azalmakta ve "ucuz hizmet" için gelen tüketici kitlesi de "kalitesiz" olmaktadır. Bu durumun, tesisleri bağlamında belirli bir kaliteye ulaşmış olan Türkiye destinasyonun marka imajını zedelediği ve ülkeye döviz girdisini engellediği belirtilmektedir (Barak, 2006).

\section{Her Şey Dahil Sisteminin Dünyadaki ve Türkiye'deki Gelişimi}

Her şey dahil paket tur sistemine yönelik uygulamalar tarihi gelişimleri açısından ele alındığında, 1950’lerin ortasında bir Fransız olimpik yüzücünün İspanya'nın Mayorka sahilinde kurmuş olduğu çadır kapsamında "konaklama”, "yeme-içme” ve "diğer hizmetleri” tek bir fiyat üzerinden sunması ile başlayan "her şey dahil”" fikrinin oldukça ilgi topladığı görülmüştür (Aktaş vd., 2002). Çevre koşullarının yetersizliğinden ve aktivite eksikliğinden her şey dahil paket tur sistemine yönelik ilk uygulamaların, çevresi “yüksek duvarlar" ve "teller”le korumaya alınmış büyük otel ve saraylarda başladığı belirtilmektedir (Yürik, 2002). II. Dünya Savaşı'ndan hemen sonra kurulan Fransız Club Mediterranee, 1960 ve 1970'li yıllar boyunca “Club Tatil” adıyla her şey dahil uygulamasının uluslararası piyasalara taşınmasını sağlamıştır. Club Mediterranee'nin öncülüğünde uygulamaya konan tüm tatiller için tek fiyat olgusunun, özellikle Karayipler destinasyonunda büyük gelişmeler kaydettiği görülmüştür. Karayipler' de yer alan adalarda onlarca her şey dahil faaliyet gösteren tesisler 
kurulmuş, bazı önemli zincir işletmelerin yeni tesisler inşa ettikleri veya eski tesislerini yeniledikleri görülmüştür. Yalnızca tesis sayılarında değil, sunulan hizmetlerde de gelişmeler olmuş, ilk dönemlerde kamp hizmetlerinin sadece bekâr kişilere yönelik verildiği görülürken günümüzde çiftlere, çocuklu kişilere ve lüks arayışındaki tatilcilere de hizmet verebilen tesislerin kurulduğu görülmektedir.

2000'li y1llara gelindiğinde Karayipler destinasyonundaki 1500 tesisin 200'ünün bütünüyle her şey dahil çalışmaya başladığı ve her şey dahil paket tur satışı yapan tesisler arasında yer aldıkları görülmüştür. Her şey dahil fikrinin Avrupa'ya, Asya’ya ve Afrika'ya taşınmasında ise Alman ve İtalyan turizm işletmelerinin etkili olduğu görülmüştür (Aktaş vd., 2002). Her şey dahil uygulamaları incelendiğinde her şey dahil turların, Hong-Kong'lu turistlerin en popüler seyahat şekli olduğu görülmektedir. Hong-Kong'lu turistlerin, her şey dahil paket turlarına katılımlarından önce seyahate yönelik bilgi edinmek amacıyla genellikle seyahat acentalarına başvurdukları belirtilmektedir. HongKong'da yer alan seyahat acentalarının da boş zamanlarını değerlendirmek için kısa veya uzun mesafelerdeki destinasyonlara gitmeyi arzulayan turistik tüketicilere "her şey dahil" paket turları sundukları belirtilmektedir. Paket tur tercihlerine yönelik yapılan araştırmalar; hizmet verilen programların, fiyatların, eş-dost tavsiyelerinin ve seyahat günlerinin uygunluğunun paket turları tercih sebepleri arasında yer aldığı sonucuna ulaşırken; turların konforunun, uygun bir atmosfer içerisinde geçme durumunun, görülmesi gereken yerlerinin ve deneyimli tur rehberlerinin hazır bir şekilde bulundurulmasının da tur tercihlerinde önem arz eden unsurlar arasında yer aldığını ortaya koymuştur. Buna ek olarak, "her şey dahil” paket turlara yönelik büyük miktarlarda ödeme yapan turistlerin, "iyi vakit geçirme", “tecrübe edinme" ve “yüksek kalitede ürün beklentisi” içerisinde oldukları belirtilmiştir.

Avrupa Birliği'nde yer alan ülkeler içerisinde ise İngilizler'in diğer ülkelerle kıyaslandığında "kapsamlı" tur taleplerinin çok daha yüksek olduğu görülmektedir. Burada, İngiltere'deki tur operatörlerinin, her şey dahil tur seyahatlerinin gelişmesine yönelik rolünün büyük olduğu belirtilmektedir. Avrupa Birliği’nde seyahat harcamalarının en fazla olduğu ülkenin ise Almanya olduğu ifade edilmektedir. Nüfus artış hızının diğer Avrupa ülkeleri ile kıyaslandığında daha yüksek olduğu görülen Fransa'nın, her şey dahil tur seyahatlerini İngiltere ve Almanya pazarlarına oranla daha az tercih ettikleri, İspanya'da ise her şey dahil tur seyahatlerini tercih eden turistik tüketicilerin sayılarının hızla arttığı görülmektedir (Clewer vd., 1992).

Her şey dahil sistemi, Türkiye destinasyonunda ise ilk defa 1990'lı yılların başlarında "Marco Polo" tatil köyünün, sonrasında da "Magic Life"1n uygulamaya koymasıyla hızlı bir şekilde gelişim göstererek diğer destinasyonlarda da yaygınlaşmaya başlamıştır (Çifçi vd., 2007). Ancak, her şey dahil 
sistemine yönelik uygulamalar incelendiğinde ve Türkiye bu sistemi uygulayan diğer ülkeler ile kıyaslandığında, Türkiye'deki her şey dahil sistem uygulamalarının birtakım farklılıklar gösterdiği dikkat çekmektedir. Bunun nedeni ise, 1990-1991'deki “Körfez Krizi”, 1993-1994'teki terör faaliyetlerinin turizm destinasyonlarını hedefe koyması, 1999'de yaşanan “Gölcük depremi” gibi nedenlerle Türk turizm endüstrisi, 1990’lı y1llarda arka arkaya zor dönemler geçirmiştir. Yaşanan bu krizlerle birlikte, aynı dönemlerde Yunanistan tarafından turizmde KDV indirimine gidilmesi de Türk turizm sektörünü negatif yönlü etkilemiştir. Yaşanan bütün bu gelişmeler neticesinde, gerçekleşmesi mümkün olan her türlü olumsuz gelişmenin gerçekleşme ihtimaline karş1, ülkede özellikle turizm faaliyetlerinin yoğun olarak gerçekleştiği güney ve güneybatı kıyı şeridinde yer alan "beş yıldızlı oteller" ve "birinci sınıf tatil köyleri”nin, bahsi geçen dönemlerde yaşadıkları "maddi kayıpları tekrar yaşamamak" ve "kendilerini güvence altına alarak doluluk oranlarını arttırabilmek" gibi amaçlarla tur operatörleriyle düşük fiyatlar üzerinden anlaşmalar yaparak her şey dahil sistemi uygulamaya başladıkları görülmüştür. Buna ek olarak, "beş yıldızlı" otellerin ve "tatil köyleri”nin yanında, pazardaki paylarını kayba uğratmak istemeyen üç ve dört yıldızlı otellerin, apart otellerin ve pansiyonların da "kendi güçleri nispetinde" her şey dahil sistemi uygulamaya başladıkları görülmüştür (Menekşe, 2005).

\section{Her Şey Dahil Sistem Konusuna İlişsin Yapılmış Çalışmalar}

Her şey dahil sistemi konusunda yapılan saha çalışmalarının bir kısmı ve varılan sonuçlar aşağıdaki gibidir:

Brown ve diğerleri tarafından 2000 yılında her şey dahil sisteme ilişkin olarak yapılan çalışmada, her şey dahil sistemin sürekli bir biçimde gelişim ve yenilik unsurlarına dayalı olduğu tespit edilmiştir. Bununla birlikte her şey dahil sistemin "başarılı" ilerleyebilme durumunun, "nitelikli insan kaynağı" ve "bölgesel yönetim ve tedarikçilerle kuvvetli bir işbirliği" unsurlarına dayalı olduğu belirtilmiştir.

Gülbahar tarafından 2002 yılında yapılan çalışmada, bölge esnafının kazancının düşmesinin esas nedeninin "her şey dahil sistem" olarak görüldüğü tespit edilmiştir. Demir tarafından 2002 yılında yapılan "Turizm işletmelerinde "her şey dahil" fiyat sisteminin maliyet ve karlılık üzerine etkilerinin analizi" adlı çalışmada, her şey dahil sisteminin "kârlı bir uygulama" olduğunun ifade edilmesine karşılık, sisteme yönelik ortaya çıkan tepkilerin de her geçen gün arttığı belirtilmiştir. Çalışmada her şey dahil sisteminde "minimum sayıda çalışan ile maksimum düzeyde iş yapılması" prensibi ile hareket edildiği ve bu sistemde konaklayan turistlerin tesisten dışarıya çıkmak istememeleri sonucunda o destinasyonda yer alan esnafın da turistlerden kazanacağı gelirlerin önünde engel oluşturduğu ve dolayısıyla yörede yer alan esnafın her şey dahil sisteminden memnun olmadıkları tespit edilmiştir. 
Issa ve Jayawardena tarafından 2003 yılında yapılan çalışmanın neticesinde araştırmacılar tarafından, Karayipler destinasyonunda uygulanmakta olan her şey dahil sisteminin çoğunlukla eleştiri almasına karşılık sistemin hızlı bir şekilde büyüme göstermeyi sürdürdüğ̈̈, sistemin konaklama sektörü içerisinde yer alan "müşteri hizmetleri” üzerinde büyük etkilerinin olduğu, sunulan hizmetin kalite bağlamında geliştirilmesine yönelik büyük rolünün olduğu ve sistemin Karayipler destinasyonunda uzun süreli olarak uygulamasını sürdüreceği ve bölge turizminin gelişimine önemli katkılar sunacağ belirtilmiştir.

Süklüm tarafından 2006 y1lında "her şey dahil sisteminin müşteri memnuniyeti üzerindeki etkisi"nin belirlenmesine ilişkin olarak gerçekleştirilen araştırmada, turistik tüketicilerin her şey dahil sistemine yönelik tercihlerinin arasında "ekstra harcamaların az olması" ve "harcamaları takip etme zorunluluğu olmaması" unsurlarının yer aldığı tespit edilmiştir. Öger Tur’un 2007 yılında Türkiye'yi ziyaret eden Alman turistlerle yaptığı anket çalışmasında, turistlerin \%85'inin her şey dahil sistem sebebiyle Türkiye'ye seyahat gerçekleştirdikleri tespit edilmiştir. Bununla birlikte, Türkiye destinasyonunda uygulanmakta olan her şey dahil sistemin, diğer ülkelerin her şey dahil sistemi uygulamalarına kıyasla “çocuklara yönelik imkanların daha fazla olması" unsurunun Türkiye’de uygulanan her şey dahil sisteminin çekiciliğini artırdığı belirtilmiştir (Üngüren vd., 2009).

Çifçi ve diğerlerinin 2007 yılında yaptıkları ve her şey dahil sisteminin Türkiye turizmini nasıl etkilediğini ele aldıkları çalışmalarında, her şey dahil sisteminin bu sistemi uygulayan işletmelerin “doluluk" ve "gelir” oranlarını arttırmasına karşılık, Türkiye turizmini olumlu yönde etkilemediğini tespit etmişlerdir. Çalışma kapsamında, konaklama işletmelerinde yer alan “oda-kahvaltı" ve "yarım pansiyon” uygulamalarının Türkiye turizmine olumlu yönde katkı sağlayan uygulamalar arasında yer aldığı belirtilmiştir.

Çevirgen ve Üngüren tarafından 2009 yılında yapılan çalışmada, Alanya destinasyonunda yer alan esnafın her şey dahil sisteme ilişkin tutumları belirlenmeye çalışılmıştır. Katılımcılar her şey dahil sisteminin Türkiye turizmine negatif etkilerinin olduğunu ve bu sistemin turizm faaliyetlerinin gerçekleştirildiği bütün destinasyonlarda uygulanmaması gerektiğini ifade ettikleri görülmüştür. Katılımcılar ayrıca, her şey dahil sisteminin varlıklı turistleri Türkiye destinasyonundan uzaklaştırdığını, dolayısıyla kârlı bir sistem olmadığını ve hizmet kalitesinde düşüşe yol açtığını belirtmişlerdir.

Yaylı ve Yayla (2012) tarafından yapılan çalışmada, turistik tüketicilerin her şey dahil sistemine yönelik tercihlerinde en önem verdikleri unsurlardan "turun iptal edilmeme garantisi", "fiyat" ve 
“fiyata dahil olanlar" unsurlarının ilk üçte yer aldığı tespit edilmiştir. Buna ek olarak, gerçekleştirilen faktör analizi neticesinde on adet faktörün belirlendiği ve bu faktörlerden "yenilikler", "fiyat" ve “seyahatin özellikleri” unsurlarının ilk üçte yer aldığı saptanmıştır.

Terzioğlu ve Gökovalı (2016), Marmaris'te 4 ve 5 yıldızlı otellerde yaptıkları araştırmada, otellerin $\% 82$ 'sinin her şey dahil sistemi uyguladıklarını, turistlerin \%82,8'inin yabancı tur operatörleri kanalıyla Türkiye'ye geldiklerini, kendi haftalık tur paketlerini pazarlayan yabancı tur operatörlerinin fiyatları belirlediğini ortaya koymuşlardır. Bunun yanında araştırmalarında, paket turlardan elde edilen gelirlerin \%55'inin Türkiye’de kaldığını, Türkiye İstatistik Enstitüsü’nün 2012 yılında gerçekleştirdiği tur operatörleri araştırmasında da bu payın \%54 olarak bulunduğunu belirtmektedirler.

Söz konusu araştırmalar değerlendirilecek olursa, çalışmalarda genel anlamda "her şey dahil sisteminin olumlu ve olumsuz yönleri”nin ele alındığı ve "Türkiye destinasyonu bağlamında turistlerin her şey dahil sistemini neden tercih ettikleri” konularına yönelik araştırmaların yeterli sayıda olmadığı sonucuna ulaşılmaktadır. Bu bağlamda bu çalışmada "her şey dahil sistemi ile konaklayan yerli ve yabancı turistlerin her şey dahil sistemini tercih nedenleri”, "her şey dahil sistemini tercih ederken önem verdikleri konular" ve "her şey dahil sisteminden memnuniyet düzeyleri” araştırılmıştır.

\section{GEREÇ ve YÖNTEM}

Çalışma, temel olarak iki bölümden oluşmaktadır. İlk bölümde; literatür kaynakları incelenerek her şey dahil sistemin konsepti araştırılmış, ekonomik açıdan olumlu ve olumsuz yönleri ortaya konulmaya çalışılmıştır. Çalışmanın ikinci bölümünde ise, Antalya ilini ziyaret ederek her şey dahil sistemi ile konaklayan yerli ve yabancı turistlerin perspektiften değerlendirilerek saha çalışması yapılmıştır. Saha çalışmasının kapsamı, ülkemizde en fazla turist kabul eden ve her şey dahil sistemin en fazla uygulandığı Antalya ili ile sınırlandırılmıştır. Zaman ve bütçe kısıtları nedeni ile Türkiye'nin farklı yöreleri araştırmaya dahil edilememiştir. Elde edilen veriler, uygun analiz teknikleri kullanılarak değerlendirilmiş, bulgular elde edilmiştir. Çalışmada son olarak elde edilen bulgular ışığında değerlendirmeler yapılmış, sonuçlar daha önce yapılan çalışmalarla karşılaştırılarak, öneriler geliştirilmeye çalışılmıştır.

\section{Saha Çalışmasının Araştırma Yöntemi: Turistler ile Anket Çalışması}

Araştırmanın saha çalışması, yerli ve yabancı turistlerin her şey dahil sistemi tercih nedenlerini, bu sisteme yönelik önem verdikleri konuları ve bu sistemden memnuniyet düzeylerini öğrenebilmek amaciyla 1 Nisan-30 Mayıs 2018 tarihleri arasında, tatillerini Antalya ilinde her şey dahil paket tur satın alarak gerçekleştiren yerli ve yabancı turistlerle yapılmıştır. Bu çalışma, yapılandırılmış anket formu aracılığıyla ve yüz yüze görüşme tekniğiyle, nicel analiz yöntemlerine uygun olarak 
gerçekleştirilmiştir. Çalışma kapsamında bütçe ve zaman kısıtlılı̆̆ı, ana kütlenin tam olarak tespit edilememesi gibi nedenlerle, tesadüfi olmayan örnekleme yöntemlerinden kolayda örnekleme yöntemi uygulanmıştır. 530 görüşme yapılmış, uygun olmadığı düşünülen anket formları araştırmadan çıkartılarak 516 anket formu analizlere tabi tutulmuştur. Veriler paket program ile analiz edilerek güvenilirliği test edilmiş, araştırmanın amacı doğrultusunda frekans dağılımları bulunmuş ve betimleyici analizler yapılmıştır.

\section{BULGULAR}

$\mathrm{Bu}$ bölümde araştırma bulgularına yer verilmiştir.

\section{Saha Çalışmasının Bulguları: Turistler ile Anket Çalışması}

Üç bölümde 40 ifadeden oluşan ölçeğin güvenilirlik katsayısı (Cronbach's Alpha), 728 olarak tespit edilmiştir. $\mathrm{Bu}$ değer, ankette yer alan ifadeler için elde edilen güvenirliğin, istatistiksel anlamda oldukça iyi düzeyde olduğunu, ölçeğin tutarlı ve güvenilir olduğunu göstermektedir.

Turistlerle yapılan anket çalışmasında 516 anket değerlendirmeye alınmıştır. Çalışmaya katılanlar ile ilgili demografik veriler Tablo 1'deki gibidir. Ankete cevap veren katılımcıların \%51,2'sinin kadın, $\%$ 48,8'inin erkek olduğu tespit edilmiştir. Katılımcıların eğitim durumları incelendiğinde, \%50,2'sinin üniversite, \%30,3’ünün lise, \%7,4'ünün ilköğretim mezunu olduğu ve \%3,1'inin lisansüstü derecesine sahip olduğu görülmektedir. Katılımcılar yaş dağılımlarına göre incelendiklerinde \%38,2'sinin 30-45 yaş aralığında, \%22,3'ünün 46-59 yaş aralığında, \%25,6’sının 18-29 yaş aralığında, \%14,0'ının ise 60 yaş ve üzerinde olduğu görülmektedir. Katılımcılar iş durumlarına göre incelendiklerinde, \%67,6'sının çalıştığı, \%13,6’sının emekli olduğu, \%11,0’ının çalışmadığı, \%7,8'inin de öğrenci olduğu anlaşılmaktadır. Katılımcılar yıllık gelir durumları açısından incelendiğinde, \%55,2'sinin 20.000 avro altında, \%17,8'inin 30.001-40.000 avro arasında, \%15,5'inin 40.001-50.000 avro arasında iken sadece \%3,5'inin yıllık gelir durumlarının 50.000 avronun üzerinde olduğu anlaşılmaktadır. Buradan hareketle, diğer çalışmalarda da teyit edildiği gibi, Antalya'da özellikle yabancı turistler için ucuz fiyatlarla her şey dahil tatil yapma imkanının olduğu ve her şey dahil paket tur konseptinde tatil yapan turistlerin genellikle düşük ve orta gelirlilerden oluştuğu söylenebilir. 
Tablo 1. Turistlerin Demografik Özellikleri

\begin{tabular}{|c|c|c|c|c|c|}
\hline & $\begin{array}{c}\text { Frekans } \\
\text { (n) }\end{array}$ & $\begin{array}{c}\text { Oran } \\
(\%)\end{array}$ & & $\begin{array}{c}\text { Frekans } \\
\text { (n) }\end{array}$ & $\begin{array}{c}\text { Oran } \\
(\%)\end{array}$ \\
\hline \multicolumn{6}{|c|}{ Yaş } \\
\hline $18-29$ & 132 & 25,6 & $46-59$ & 115 & 22,3 \\
\hline $30-45$ & 197 & 38,2 & 60 ve üstü & 72 & 14,0 \\
\hline \multicolumn{6}{|c|}{ Cinsiyet } \\
\hline Kadın & 264 & 51,2 & Erkek & 252 & 48,8 \\
\hline \multicolumn{6}{|c|}{ Eğitim Durumu } \\
\hline İlköğretim & 38 & 7,4 & Üniversite & 259 & 50,2 \\
\hline Lise & 203 & 39,3 & Yüksek Lisans/Doktora & 16 & 3,1 \\
\hline \multicolumn{6}{|c|}{ İş Durumu } \\
\hline Çalışan & 349 & 67,6 & Öğrenci & 40 & 7,8 \\
\hline Emekli & 70 & 13,6 & Çalışmayan & 57 & 11,0 \\
\hline \multicolumn{6}{|c|}{ Yıllık Gelir Durumu } \\
\hline 20.000 avro altı & 285 & 55,2 & $40.001-50.000$ aras1 & 80 & 15,5 \\
\hline 20.000-30.000 avro aras1 & 41 & 7,9 & 50.001 avro ve üstü & 18 & 3,5 \\
\hline $30.001-40.000$ avro aras1 & 92 & 17,8 & & & \\
\hline \multicolumn{6}{|c|}{ Araştırmaya Katılan Turistlerin Uyrukları } \\
\hline Türk & 86 & 16,7 & Ukraynalı & 94 & 18,2 \\
\hline Alman & 90 & 17,4 & İngiliz & 60 & 11,6 \\
\hline Rus & 156 & 30,2 & Hollandalı & 30 & 5,8 \\
\hline
\end{tabular}

Katılımcılar seyahat biçimleri doğrultusunda incelendiği zaman, Tablo 2'deki veriler elde edilmiştir. Tablo 2 incelendiğinde katılımcıların \%63,6'sının tatile aileleri ile birlikte, \%22,5'inin arkadaşı veya arkadaşları ile birlikte, \%14,0'ının ise yalnız geldikleri görülmektedir. Bu bulgular da her şey dahil sistemin genellikle aile ve arkadaş grupları tarafından tercih edildiğini göstermektedir. Katılımcıların hangi tür konaklama tesisinde konakladıkları incelendiğinde, \%64,1'inin 4 yıldızlı otelde, \%26,7'sinin 5 yıldızlı otelde, \%9,1'inin ise 3 yıldızlı otelde konakladıkları anlaşılmaktadır. Katılımcılar konaklama türlerine göre incelendiğinde bütün katılımcıların paket turu tercih ettiği; bunların \%79,5'inin her şey dahil, \%12,2'sinin tam pansiyon, \%8,3'ünün ultra her şey dahil paket turda konakladıkları görülmektedir. Katılımcılar otelde kalınan geceleme sürelerine göre incelendiğinde, büyük oranda haftalık turları tercih ettikleri dikkat çekmektedir. Katılımcıların otelde geceleme süreleri incelendiğinde $\% 36,8$ 'inin 5 gece, $\% 26,9$ 'unun 6 gece ve $\% 16,3$ 'ünün 7 gece ve üstü konakladıkları belirlenmiştir. Elde edilen bu veriler de paket turların genellikle haftalık olarak düzenlendiğini göstermektedir. Katılımcıların \%66,9'u tatil paketini tur operatöründen aldığını, \%22,5'i online (çevrimiçi) tatil sitelerinden aldığını, 10,7'si ise tatili bireysel olarak organize ettiklerini belirtmişlerdir. Elde edilen sonuçlar, tur operatörlerinin her şey dahil paket tur tatillerindeki önemli rolünü ortaya koymaktadır.

Katılımcıların \%81'i tatil süresince otel dışındaki aktivitelere katılmadığını belirtirken, \%19,0'1 otel dışında da bazı etkinliklere katıldıklarını belirtmiştir. Bu bulgular, konu ile ilgili yapılan diğer araştırmaları da destekler niteliktedir. Her şey dahil sistemin en olumsuz yönlerinden birisi, tatil yapan 
turistlerin zamanlarını konaklama tesisi içerisinde geçirmesidir. Bu durumda yerel işletmeler, müze ve ören yerleri gibi oluşumlar, turizm faaliyetinden yeterli payı alamamaktadır. Bu çalışmadan elde edilen bulgulara göre de katılımcıların sadece \%6,0'1 müze ziyaretinde bulunmuş, \%7,0’1 çevre gezine katılmış, \%3,9'u alışveriş yapmış, \%1,6'sı tarihi alanları ziyaret etmiş ve 0,6'sı bir konsere gitmiştir. Tatil için yapılan kişi başı harcamalar incelendiğinde, katılımcıların \%17,7'sinin 200 avrodan az harcama yaptığı, \%37,9’unun 200-299 avro arasında harcama yaptığı, \%27,5'inin 300-399 avro arasında ve \%15,9'unun 400-499 avro arasında harcama yaptı̆̆ı anlaşılmaktadır. Katılımcıların sadece \%1,0’1 500 ve üzeri avro harcama yaptığını belirtmiştir. Bu bulgular da benzer çalışmaları doğrulamaktadır. Her şey dahil paket tura katılanlar, tur operatörlerin pazarlama gücü sayesinde özellikle kriz dönemlerinde çok uygun fiyatlara tatil yapabilmektedirler. Çalışmanın yapıldığg dönem olan 1 Nisan-30 Mayıs 2018 tarihleri göz önüne alındığında çalışmanın saha araştırması, Türkiye ile Rusya arasındaki krizin yeni yeni geçtiği, AB ülkeleri ile krizin yaşandığı bir dönemde gerçekleştirilmiştir.

Tablo 2. Turistlerin Seyahat Şekilleri ile İlgili Bulgular

\begin{tabular}{|c|c|c|c|c|c|}
\hline & $\begin{array}{l}\text { Frekans } \\
\text { (n) }\end{array}$ & Oran (\%) & & $\begin{array}{l}\text { Frekans } \\
\text { (n) }\end{array}$ & $\begin{array}{c}\text { Oran } \\
(\%)\end{array}$ \\
\hline \multicolumn{6}{|c|}{ Kimlerle Seyahat Ediliyor } \\
\hline Yalnız & 72 & 14,0 & Arkadaşım/ arkadaşlarım ile & 116 & 22,5 \\
\hline Ailem ile & 328 & 63,6 & & & \\
\hline \multicolumn{6}{|c|}{ Konaklama_tesisi } \\
\hline 3 y1ldiz otel & 47 & 9,1 & 5 yıldızlı otel & 138 & 26,7 \\
\hline 4 yıldiz otel & 331 & 64,1 & & & \\
\hline \multicolumn{6}{|c|}{ Otelde konaklama türü } \\
\hline Tam pansiyon & 63 & 12,2 & Ultra her şey dahil & 43 & 8,3 \\
\hline Her şey dahil & 410 & 79,5 & & & \\
\hline \multicolumn{6}{|c|}{ Otelde geceleme süresi } \\
\hline 2 gece ve alt1 & 11 & 2,1 & 5 gece & 190 & 36,8 \\
\hline 3 gece & 30 & 5,8 & 6 gece & 139 & 26,9 \\
\hline 4 gece & 62 & 12,0 & 7 gece ve üstü & 84 & 16,3 \\
\hline \multicolumn{6}{|c|}{ Tatilin organize şekli } \\
\hline Bireysel & 55 & 10,7 & Online (Çevrimiçi) & 116 & 22,5 \\
\hline Tur operatörü ile & 345 & 66,9 & & & \\
\hline \multicolumn{6}{|c|}{ Tatil süresince otel dışındaki aktivitelere katılma durumu } \\
\hline Evet, katıldım. & 98 & 19,0 & Hayır, katılmadım. & 418 & 81,0 \\
\hline \multicolumn{6}{|c|}{ Otel dışında katılınan aktivite } \\
\hline Müze & 31 & 6,0 & Çevre gezisi & 36 & 7,0 \\
\hline Konser & 3 & 0,6 & Tarihi alanları ziyaret & 8 & 1,6 \\
\hline Alışveriş & 20 & 3,9 & & & \\
\hline \multicolumn{6}{|c|}{ Bu tatil için kişi başı ortalama yapılan harcama (avro) } \\
\hline 100 - 199 avro arası & 91 & 17,7 & 400 - 499 avro arası & 82 & 15,9 \\
\hline $200-299$ avro aras1 & 195 & 37,9 & 500 ve üzeri avro & 5 & 1,0 \\
\hline 300 - 399 avro aras1 & 142 & 27,5 & & & \\
\hline
\end{tabular}


Katılımcıların Antalya'yı daha önceden ziyaret edip etmedikleri, Antalya'yı tekrar ziyaret edip etmeyecekleri ile ilgili sorulara verdikleri cevaplar Tablo 3'teki gibidir. Katılımcıların \%40,7'si Antalya'ya ilk defa geldiklerini, \%29,1'i daha önce bir defa geldiklerini, \%18,2'si iki defa geldiklerini, $\% 12,0$ '1 ise Antalya'ya daha önce üç ve üstü defa geldiklerini belirtmiştir. Katılımcılara daha önce Antalya'da her şey dahil sistem tatil yapıp yapmadıkları sorulduğunda, katılımcıların \%47,3'ü Antalya'da ilk defa her şey dahil sistem tatil yaptığını, \%44,8'i daha önce bir defa Antalya'da her şey dahil sistem tatil yaptığını, \%7,9'u ise daha önce iki defa Antalya'da her şey dahil sistem tatil yaptı̆̆ını belirtmiştir. Katılımcılara Antalya'yı tekrar ziyaret etme niyetleri sorulduğunda \%78,5'i "Evet, düşünüyorum”, \%21,5'i ise "Emin değilim” cevabını vermiştir. Benzer oranlarda katılımcıların \%80,2'si Antalya'da tekrar her şey dahil tatil sistem tatil yapmayı düşündüklerini, \%19,8'i ise emin olmadıklarını belirtmiştir. Tablo 3'e göre “Antalya'yı tekrar ziyaret etmek istemiyorum” ve "Antalya'da tekrar her şey dahil tatil yapma düşüncem yok" cevabını veren hiçbir katılımcının olmadığı dikkat çekmektedir.

Tablo 3. Turistlerin Antalya Seyahati ile İlgili Bulgular

\begin{tabular}{|c|c|c|c|c|c|}
\hline & $\begin{array}{c}\text { Frekans } \\
\text { (n) }\end{array}$ & $\begin{array}{c}\text { Oran } \\
(\%)\end{array}$ & & $\begin{array}{c}\text { Frekans } \\
\text { (n) }\end{array}$ & $\begin{array}{c}\text { Oran } \\
(\%)\end{array}$ \\
\hline \multicolumn{6}{|c|}{ Antalya'yı daha önceden ziyaret etme durumu } \\
\hline Hiç etmedim & 210 & 40,7 & 2 defa & 94 & 18,2 \\
\hline 1 defa & 150 & 29,1 & 3 ve üstü defa & 62 & 12,0 \\
\hline \multicolumn{6}{|c|}{ Antalya'da daha önceden her şey dâhil tatil yapma durumu } \\
\hline Hiç yapmadım & 244 & 47,3 & 2 defa & 41 & 7,9 \\
\hline 1 defa & 231 & 44,8 & & & \\
\hline \multicolumn{6}{|c|}{ Antalya'yı tekrar ziyaret etme düșüncesi } \\
\hline Evet düşünüyorum & 405 & 78,5 & Emin değilim & 111 & 21,5 \\
\hline \multicolumn{6}{|c|}{ Antalya'da tekrar her şey dâhil tatil yapma düşüncesi } \\
\hline Evet düşünüyorum & 414 & 80,2 & Emin değilim & 102 & 19,8 \\
\hline
\end{tabular}

Araştırmada kullanılan beşli likert ölçeği, kişilerin verilen önermelerle ilgili görüşlerini belirlemesi için çok olumsuzdan, çok olumluya doğru sıralanmıştır. Buna göre önermelere, ifadelere uygun olacak biçimde; (1) "Hiç katılmıyorum”, (2) “Katılmıyorum”, (3) "Kısmen katılıyorum”, (4) "Katılıyorum”, (5) "Tamamen katılıyorum" gibi Tablo 4'te belirtilen şekilde puan verilmiştir. İfadelerin değerlendirilmesinde Tablo 4’teki puan aralığına göre değerlendirme yapılmıştır.

Tablo 4. Beşli Likert Ölçeği Değerlendirme Tablosu

\begin{tabular}{|l|c|c|c|c|c|}
\hline Değerlendirme & $\begin{array}{c}\text { "Hiç } \\
\text { katılmiyorum" }\end{array}$ & "Katılmiyorum" & $\begin{array}{c}\text { "Kismen } \\
\text { katıllyorum" }\end{array}$ & "Katıllyorum" & $\begin{array}{c}\text { "Tamamen } \\
\text { katılliyorum" }\end{array}$ \\
\hline & $\begin{array}{c}\text { "Hiç önemli } \\
\text { değil" }\end{array}$ & "Önemli değil" & "Biraz önemli" & "Önemli" & "Çok önemli" \\
& $\begin{array}{c}\text { "Hiç memnun } \\
\text { değilim" }\end{array}$ & $\begin{array}{c}\text { "Memnun } \\
\text { değilim" }\end{array}$ & $\begin{array}{c}\text { "Biraz } \\
\text { memnunum" }\end{array}$ & "Memnunum" & $\begin{array}{c}\text { "Çok } \\
\text { memnunum" }\end{array}$ \\
\hline Puan & $1,00-1,79$ & $1,80-2,59$ & $2,60-3,39$ & $3,40-4,19$ & $4,20-5,00$ \\
\hline
\end{tabular}

Kaynak: http://www.istatistikanaliz.com/faktor_analizi.asp 
Ölçeğin ilk bölümünde katılımcıların her şey dahil paket tur satın almalarının nedeni ile ilgili ifadelere verdikleri cevaplar Tablo 5'te yer almaktadır. Tablodan da anlaşılacağı gibi katılımcıların katılmadıkları bir ifade bulunmamaktadır. Katılımcıların katılım derecesine göre ulaşılan bulgular Tablo 5'te sıralandığı gibidir. Tamamen katılınan ifadeler, “çocuk bakım hizmetlerinin (özel çocuk oyun alanlarının, çocuk havuzunun, çocuk parkının, çocukların görevliler tarafından gözetlenmesi gibi) otel tarafından sağlanması”, "otel programının (günün farklı zamanlarında farklı mekanlarda yiyecek içecek imkanları, eğlence imkanları gibi) esnek olması”dır. "Ödenen paranın karşılığının alınması", "daha az harcama ile daha fazla hizmet alınması", "kısıtlı bir zaman periyodu içerisinde daha fazla spor etkinliğine katılma imkânı sağlanması" gibi ifadelere katılım ortalaması daha sonra siralanmaktadır.

Tablo 5. Turistlerin Tatillerini Her Şey Dahil Paket Tur ile Satın Alma Nedenleri

\begin{tabular}{|c|c|c|c|c|}
\hline & Minimum & Maksimum & Ortalama & $\begin{array}{c}\text { Std. } \\
\text { Sapma }\end{array}$ \\
\hline \multicolumn{5}{|c|}{ Turistlerin tamamen katıldıklarını belirttikleri ifadeler (Ortalama 4,20 ve üstï) } \\
\hline "Çocuk bakım hizmetlerinin sağlanması" & 4,00 & 5,00 & 4,9535 & ,21079 \\
\hline "Otel programının esnek olması" & 4,00 & 5,00 & 4,9535 &, 21079 \\
\hline "Ödenen paranın karşılığının alınması" & 4,00 & 5,00 & 4,7209 & ,44898 \\
\hline $\begin{array}{l}\text { "Daha az harcama ile daha fazla hizmet almayı } \\
\text { sağlaması" }\end{array}$ & 4,00 & 5,00 & 4,7209 & ,44898 \\
\hline $\begin{array}{l}\text { "Kısıtlı bir süre zarfı içerisinde daha fazla spor } \\
\text { etkinliğine katılma imkânı sağlaması" }\end{array}$ & 4,00 & 5,00 & 4,7209 & ,44898 \\
\hline "Güvenli ulaşım sağlaması" & 3,00 & 5,00 & 4,4671 &, 65425 \\
\hline "Seyahati organize etmeye gerek bırakmaması" & 4,00 & 5,00 & 4,3837 & ,48676 \\
\hline "Dinlenmek için daha fazla zaman sağlaması" & 4,00 & 5,00 & 4,3837 & 48676 \\
\hline $\begin{array}{l}\text { "Sosyal ilişkilerin kurulmasına imkân } \\
\text { sağlaması" }\end{array}$ & 3,00 & 5,00 & 4,3140 &, 66703 \\
\hline "Hijyen standartlarında endișeye yer vermemesi" & 3,00 & 5,00 & 4,2888 & 65947 \\
\hline "Ekstra harcama yapılmasını önlemesi" & 4,00 & 5,00 & 4,2791 & ,44898 \\
\hline "Yiyeceklerin kaliteli olması" & 3,00 & 5,00 & 4,2791 & 68523 \\
\hline \multicolumn{5}{|c|}{ Turistlerin katıldıklarını belirttikleri ifadeler (Ortalama 3,40-4,19 arası) } \\
\hline "Ailem için daha uygun olması" & 4,00 & 5,00 & 4,0465 & ,21079 \\
\hline $\begin{array}{l}\text { "Ziyaret edilen destinasyonda güvende } \\
\text { hissettirmesi" }\end{array}$ & 2,00 & 5,00 & 4,0194 & ,97921 \\
\hline 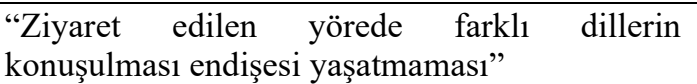 & 2,00 & 5,00 & 3,4729 & 1,01696 \\
\hline "Yabancı kültür endişesi yaşatmaması" & 2,00 & 5,00 & 3,4496 & 1,03313 \\
\hline
\end{tabular}

Katılımcılara sorulan "tatillerini her şey dahil paket tur ile satın alırken konuların önem derecesi”" ifadelerine verdikleri cevaplar Tablo 6'da yer almaktadır. Tablodan da anlaşılacağı üzere, katılımcıların katılmadıkları bir ifade bulunmamaktadır. Katılımcıların katılım derecesine göre ulaşılan bulgular Tablo 6'da sıralandığg gibidir. Her şey dahil paket tur alırken katılımcıların en önem verdikleri konuların "otelin sosyal medyadaki genel değerlendirmesi" ve "aile ve arkadaş tavsiyeleri" olduğu görülmektedir. "Turun güvenliğgi”, “turun içerdiği yemek sayısı”, “tur operatörünün bilinirliği”" ve diğer konular, Tablo 6'da verildiği gibi daha sonra sıralanmaktadır. 
Tablo 6. Turistlerin Tatillerini Her Şey Dahil Satın Alırken Konuların Önem Derecesi

\begin{tabular}{|c|c|c|c|c|}
\hline & Minimum & Maksimum & Ortalama & $\begin{array}{c}\text { Std. } \\
\text { Sapma }\end{array}$ \\
\hline \multicolumn{5}{|c|}{$\begin{array}{c}\text { Her şey dahil paket tur ile satın alırken turistlerin çok önemli olduğunu belirttikleri ifadeler } \\
\text { (Ortalama 4,20 ve üstü) }\end{array}$} \\
\hline "Otelin sosyal medyadaki genel değerlendirmesi" & 4,00 & 5,00 & 4,6860 & ,46455 \\
\hline "Aile ve arkadaş tavsiyeleri" & 4,00 & 5,00 & 4,6860 & ,46455 \\
\hline "Turun güvenliği”" & 4,00 & 5,00 & 4,6163 & ,48676 \\
\hline "Turun içerdiği yemek sayısı" & 4,00 & 5,00 & 4,6163 & ,48676 \\
\hline "Tur operatörünün bilinirliği” & 4,00 & 5,00 & 4,6047 & ,48940 \\
\hline "Turun iptal edilmeme garantisi" & 4,00 & 5,00 & 4,3953 & ,48940 \\
\hline "Tur fiyatına dahil olan hizmetler" & 4,00 & 5,00 & 4,3837 & ,48676 \\
\hline "Çocuk indirimi sağlanması" & 4,00 & 5,00 & 4,3837 & ,48676 \\
\hline "Seyahatin gün sayısı" & 4,00 & 5,00 & 4,3837 & ,48676 \\
\hline "Kişisel ilgi alanları" & 4,00 & 5,00 & 4,3837 & ,48676 \\
\hline "Turun fiyatı" & 4,00 & 5,00 & 4,3372 &, 47322 \\
\hline "Oda veya yatak için özel isteklere açık olması" & 4,00 & 5,00 & 4,3372 &, 47322 \\
\hline "Destinasyonun bilinirliği" & 4,00 & 5,00 & 4,3372 & ,47322 \\
\hline \multicolumn{5}{|c|}{$\begin{array}{l}\text { Her şey dahil paket tur ile satın alırken turistlerin önemli olduğunu belirttikleri ifadeler } \\
\text { (Ortalama 3,40-4,19 arası) }\end{array}$} \\
\hline "Kullanılan havayolları şirketi" & 3,00 & 5,00 & 4,1318 & ,89338 \\
\hline "Otelin kalitesi ve yıldız derecesi" & 4,00 & 5,00 & 4,0349 & ,18366 \\
\hline "Alkollü içeceklerin ücretsiz olması" & 2,00 & 5,00 & 3,5988 & 1,09363 \\
\hline "Uçuş programı" & 2,00 & 5,00 & 3,5872 & 1,25030 \\
\hline
\end{tabular}

Katılımcıların her şey dahil Antalya tatillerini değerlendirmeleri amacıyla sorulan ifadelere verdikleri cevaplar Tablo 7'deki gibidir. Tablodan görüleceği üzere katılımcıların çok memnun kaldıkları, memnun kalmadıkları veya hiç memnun kaldıkları bir konu yoktur. Memnun kaldıkları ve kısmen memnun kaldıkları konular, memnuniyet derecesine göre Tablo 7'de sıralanmaktadır. Bu bulgulara göre "fiyat", "yiyecek ve içeceklerin çeşitliliği”", "yiyecek ve içeceklerin kalitesi” ve "rekreasyonel aktivitelerin çeşitliliği” memnun kalınan konular arasındadır. "Konaklama işletmesinin kalitesi”, "rekreasyonel aktivitelerin kalitesi" ve "temizlik ve hijyen” konuları ise kısmen memnun kalınan konular arasında yer almaktadır.

Tablo 7. Turistlerin Antalya Tatilinde Konakladıkları Otellerin Değerlendirilmesi

\begin{tabular}{|c|c|c|c|c|}
\hline Ífadeler & Minimum & Maksimum & Ortalama & $\begin{array}{c}\text { Std. } \\
\text { Sapma }\end{array}$ \\
\hline \multicolumn{5}{|c|}{$\begin{array}{c}\text { Turistlerin Antalya'da her şey dahil tatillerinde memnun kaldıkları konular } \\
\text { (Ortalama 3,40-4,19 arası) }\end{array}$} \\
\hline "Fiyat" & 2,00 & 5,00 & 3,7810 &, 81521 \\
\hline "Yiyecek ve içeceklerin çeşitliliği”" & 3,00 & 4,00 & 3,6860 & ,46455 \\
\hline "Yiyecek ve içeceklerin kalitesi" & 3,00 & 4,00 & 3,6860 & ,46455 \\
\hline "Rekreasyonel aktivitelerin çeşitliliği”" & 2,00 & 5,00 & 3,4438 & ,79972 \\
\hline \multicolumn{5}{|c|}{$\begin{array}{l}\text { Turistlerin Antalya'da her şey dahil tatillerinde kısmen memnun kaldıkları konular } \\
\text { (Ortalama 2,60-3,39 arası) }\end{array}$} \\
\hline "Konaklama işletmesinin kalitesi" & 3,00 & 5,00 & 3,3798 & ,52796 \\
\hline "Rekreasyonel aktivitelerin kalitesi" & 3,00 & 4,00 & 3,3469 & ,47645 \\
\hline "Temizlik ve hijyen" & 2,00 & 4,00 & 3,3101 & ,53678 \\
\hline
\end{tabular}




\section{SONUÇ ve TARTIŞMA}

Her şey dahil sisteme yönelik yapılmış çalışmalar incelediğinde (Brown vd., 2000; Gülbahar, 2002; Süklüm, 2006; Çifçi vd., 2007; Çevirgen ve Üngüren, 2009; Yaylı ve Yayla, 2012; Terzioğlu ve Gökovalı, 2016), söz konusu çalışmaların genellikle "her şey dahil sisteminin olumlu ve olumsuz yönlerinden" bahsettiği ve turistlerin Türkiye destinasyonunda "her şey dahil sistemini neden tercih ettikleri ve bu sistemden memnuniyet düzeyleri” konuları doğrultusunda gerçekleştirilmiş araştırmaların yeterli sayıda olmadığı dikkat çekmektedir. Bu bağlamda bu çalışmada, Antalya'yı ziyaret eden ve her şey dahil sistemi ile konaklayan yerli ve yabancı turistlerin her şey dahil sistemini tercih nedenleri, her şey dahil sisteme yönelik tercihlerinde önemli buldukları konular ve her şey dahil sistemden memnuniyet düzeyleri ortaya çıkarılmaya çalışılmıştır.

Çalışmaya katılan 516 turistin \%51,2'sinin kadın, \%50,2'sinin üniversite mezunu, \%38,2'sinin 30-45 yaş aralığında, \%67,6'sının çalıştığı, \%55,2'sinin 20.000 avro altında yıllık gelire sahip oldukları ve \%63,6'sının tatile aileleri ile birlikte geldikleri tespit edilmiştir. Bu bulgular da her şey dahil sistemin genellikle aile ve arkadaş grupları tarafından tercih edildiğini göstermektedir. Katılımcıların \%64,1'inin 4 yıldızlı otelde konakladıkları, \%79,5'inin her şey dahil paket tur satın aldıkları ve büyük oranda haftalık turları tercih ettikleri dikkat çekmektedir. Katılımcıların \%81'inin tatil süresince otel dışındaki aktivitelere katılmadığını belirttikleri görülmüştür. Katılımcıların sadece \%6,0'sının müze ziyaretinde bulundukları, \%7,0'^nın çevre gezine katıldıkları, \%3,9'unun alışveriş yaptıkları, \%1,6'sının tarihi alanları ziyaret ettikleri ve 0,6'sının bir konsere katıldıkları saptanmıştır. Bu bulgular, konu ile ilgili yapılan diğer çalışmaları da destekler niteliktedir. Her şey dahil sistemin en olumsuz yönlerinden birisi, tatil yapan turistlerin zamanlarını konaklama tesisi içerisinde geçirmesidir. Bu durumda yerel işletmeler, müze ve ören yerleri gibi oluşumlar, turizm faaliyetinden yeterli payı alamamaktadır. Katılımcıların tatil için yaptıkları kişi başı harcamalar incelendiğinde, \%17,7'sinin 200 avrodan az harcama yaptıkları, \%37,9'unun 200-299 avro arasında harcama yaptıkları, \%27,5'inin 300-399 avro arasında ve \%15,9'unun 400-499 avro arasında harcama yaptıkları tespit edilmiştir. Katılımcıların sadece \%1,0’’nın 500 ve üzeri avro harcama yaptığı belirlenmiştir. Ulaşılan bu sonuçlar, daha önce konu ile ilgili yapılan çalışmaları da doğrular niteliktedir. Her şey dahil paket turlara katılanlar, genellikle düşük ve orta gelir seviyesindeki kişilerden oluşmaktadır. Her şey dahil paket tur sistemi, daha çok aileler ve gruplar tarafından tercih edilmektedir. Her şey dahil tatil yapanlar, genellikle otel dışına çıkmamakta; dolayısıyla yerel ekonomiye ve yerel işletmelere katkıları çok az olmaktadır. 
Katılımcıların \%40,7'sinin Antalya'ya ilk defa geldikleri; \%47,3'ünün Antalya'da ilk defa her şey dahil sistem tatil yaptıkları, \%44,8'inin ise daha önce bir defa Antalya'da her şey dahil sistem tatil yaptıkları tespit edilmiştir. Katılımcıların \%78,5 oranında Antalya'yı tekrar ziyaret etme düşüncelerinin olduğu; \%80,2'sinin Antalya'da tekrar her şey dahil tatil sistem tatil yapmayı düşündükleri görülmüştür. Ulaşılan sonuçlar arasında “Antalya'yı tekrar ziyaret etmek istemiyorum” ve "Antalya'da tekrar her şey dahil tatil yapma düşüncem yok" cevabını veren hiçbir katılımcının olmadığı dikkat çekmektedir. Buradan hareketle Antalya ilini ziyaret eden ve her şey dahil paket tur tatili yapan yerli ve yabancı turistlerin Antalya ilinden ve her şey dahil paket tur tatil sisteminden memnun oldukları söylenebilir. Dolayısıyla her şey dahil paket tur sistemini uygulayan konaklama işletmelerine ve Antalya yerel yönetimine hizmet kalitesini aynı ölçüde devam ettirmeleri önerilebilir.

Katılımcıların her şey dahil paket tur satın almalarının nedeni ile ilgili ifadelere verdikleri cevaplarda “çocuk bakım hizmetlerinin (özel çocuk oyun alanlarının, çocuk havuzunun, çocuk parkının, çocukların görevliler tarafından gözetlenmesi gibi) otel tarafından sağlanması”, "otel programının (günün farklı zamanlarında farklı mekanlarda yiyecek içecek imkanları, eğlence imkanları gibi) esnek olması" konularının, katılımcılar tarafından tamamen katılınan ifadeler arasında yer aldığı görülmektedir. "Ödenen paranın karşılığının alınması", "daha az harcama ile daha fazla hizmet alınması", "kısıtlı bir zaman periyodu içerisinde daha fazla spor etkinliğine katılma imkânı sağlanması" gibi ifadelere katılım ortalamalarının ise daha sonra sıralandığı dikkat çekmektedir. Bununla birlikte her şey dahil paket tur alırken katılımcıların en önem verdikleri konuların "otelin sosyal medyadaki genel değerlendirmesi” ve “aile ve arkadaş tavsiyeleri” konuları olduğu görülmüştür. "Turun güvenliği”, "turun içerdiği yemek sayısı" ve "tur operatörünün bilinirliği"” konularının ise daha sonra sıralandığı görülmektedir. Her şey dahil paket tur alırken katılımcıların en önem verdikleri konuların "otelin sosyal medyadaki genel değerlendirmesi” ve "aile ve arkadaş tavsiyeleri" olması, tüketiciler tarafından sosyal medyada oluşturulan çeşitli mesajların farkındalık, bilgi, kanı, tutum kazanma, satın alma, satın alma sonrası iletişim ve değerlendirme gibi tüketici davranışlarını önemli ölçüde etkilediğine işaret etmektedir. Buradan hareketle her şey dahil paket tur sistemini uygulayan konaklama işletmelerine etkili bir sosyal medya yönetimi yapmaları önerilmektedir. Böylece söz konusu konaklama işletmeleri sosyal medya ortamında aktif bir şekilde var olarak haklarında çıkan kötü haber ve yorumları krize dönüşmeden çözüme kavuşturacak ve müşterilerinin şikâyet ve önerilerini dinleyerek onlarla diyaloglarını geliştirecek ve sadık müşteriler yaratacaklardır. 
Katılımcıların her şey dahil Antalya tatillerini değerlendirmeleri amacıyla sorulan ifadelerden memnun kaldıkları ve kısmen memnun kaldıkları konular arasında "fiyat”, "yiyecek ve içeceklerin çeşitliliği”, “yiyecek ve içeceklerin kalitesi” ve "rekreasyonel aktivitelerin çeşitliliği” konularının memnun kalınan konular arasında yer aldığı görülmüştür. "Konaklama işletmesinin kalitesi”, "rekreasyonel aktivitelerin kalitesi" ve "temizlik ve hijyen" konularının ise kısmen memnun kalınan konular arasında yer aldığı tespit edilmiştir. Dolayısıyla her şey dahil paket tur uygulayan otel işletmelerinde konaklayan müşterilerin, otelin tüm bölümlerinde sunulan hizmetlerden memnuniyet düzeylerinin yüksek olmasının söz konusu işletmelere sağlayacağı sadakat artışı ve bu doğrultuda işletmenin yeniden tercih edilecek olması, kârlılıkta sağlayacağı artış vb. gibi birçok fayda göz önüne alındığında, kısmen memnun kalınan konular olan "konaklama işletmesinin kalitesi”, "rekreasyonel aktivitelerin kalitesi" ve "temizlik ve hijyen" konularının söz konusu otel işletmeleri tarafından tekrar ele alınması ve çözüm odaklı bakış açısıyla değerlendirilmesi önerilebilir.

$\mathrm{Bu}$ araştırma, yerli ve yabancı turistlere yönelik bu turistlerin "her şey dahil sistemi”ni tercih nedenlerini, "her şey dahil sistemi”ni tercih süreçlerinde önemli gördükleri konuları ve "her şey dahil sistem"den memnuniyet düzeylerini belirlemeye yönelik olarak Antalya ilinde gerçekleştirilmiştir. Saha araştırmasının sadece Antalya ilinde yapılması, çalışmanın temel sınırlılığını oluşturmaktadır. Gelecek çalışmalar için araştırmacılara diğer illeri de çalışma kapsamına dahil etmeleri ve daha fazla katılımcıyla konuyu daha ayrıntılı bir şekilde ele almaları önerilmektedir. Böylece, turistlerin her şey dahil sistemi tercih nedenlerine, bu sistemi tercih ederken önem verdikleri konulara ve her şey dahil sisteminden memnuniyet düzeylerine yönelik daha genellenebilir ve kıyaslanabilir sonuçlara ulaşmanın; yorum ve önerilerin de bu doğrultuda yapılmasının daha mümkün kılınabilir olacağı ifade edilebilir. 


\section{KAYNAKÇA}

Aksu, A., Özdemir, B., Bato Çizel, R., Tarcan İçigen, E., Çizel, B., \& Ehtiyar, R. (2008). Antalya Yöresi Turist Profili Araştırması. Antalya: Akdeniz Üniversitesi Turizm İşletmeciliği ve Otelcilik Yüksekokulu, AKTOB (Akdeniz Turistik Otelciler ve İşletmeciler Birliği) ve ICF Airports.

Aktaş, A., Özdemir, B., Tarcan, E., \& Atılgan, E. (2002). Türkiye Genelinde Her Şey Dahil Uygulamasının Turistler, İşletme Yöneticileri ve Yöre Esnafi Açısından Değerlendirilmesine Yönelik Bir Araştırma, Akdeniz Ülkeleri Turizm Kongresi, Antalya: 621-648.

Alaeddinoğlu, F., \& Can, A. S. (2007). Türk Turizm Sektöründe Tur Operatörleri ve Seyahat Acenteleri. Ticaret ve Turizm Eğitim Fakültesi Dergisi, 2, 50-66.

Anderson, W. (2012). Analysis of "All-Inclusive" Tourism Mode in the Balearic Islands. Tourismos: An International Multidisciplinary Journal of Tourism, 7 (1), 309-323.

Barak, H. (2006). Turizm Sektöründe Uygulanan Herşey Dahil Tatil Sisteminin Bölgedeki İşletmeler Üzerindeki Etkisi ve Bodrum Örneği. Doktora Tezi, DEÜ Sosyal Bilimler Enstitüsü, İzmir.

Boz, M. (2004). Turizmin Gelişmesinde Alternatif Turizm Pazarlamasının Önemi. Yayınlanmamış Doktora Tezi, Marmara Üniversitesi Sosyal Bilimler Enstitüsü, İstanbul.

Brown, D., Elmes, L., \& Medina, G. Y. (2000). A Study of the All-inclusive Sector in the Caribbean with Emphasis on Dominican Republic and Jamaica, Graduate Paper, The University of the West Indies, Jamaica.

Clewer, A., Pack, A., \& Sinclair, M. T. (1992). Price Competitiveness and Inclusive Tour Holidays in European Cities. Price Competitiveness and Inclusive Tour Holidays in European Cities., 123-143.

Cojocariu, S. (2015). The Development of Cultural Routes: A Valuable Asset for Romania. Procedia Economics and Finance, 32, 959-967.

Çelik, Y. (2017). Gözde ürün Türkiye, "en ucuz tatil destinasyonu” haline geldi. https://www.turizmgunlugu.com/2017/05/11/gozde-urun-turkiye-en-ucuz-tatildestinasyonu-haline-geldi/, (24.10.2020).

Çevirgen, A., \& Üngüren, E. (2009). Yöre Esnafının Herşey Dahil Sistemine Yönelik Tutumları. Ege Akademik Bakış Dergisi, 9(2), 637-658.

Çifçi, H., Düzakın, E., \& Önal, Y. B. (2007). All Inclusive System and Effects on the Turkish Tourism Sector. Problems and Perspectives in Management, 5(3), 269275.

Datar, R. (2012). Are All-Inclusive Holidays Creating Ghost Towns? http://news.bbc.co.uk/2/hi/programmes/fast_track/9567917.stm. (30.01.2018). 
Demir, F. Ö. (2002). Turizm İşletmelerinde Herşey Dahil Fiyat Sisteminin Maliyet Ve Karlılık Üzerine Etkisinin Analizi. Yayınlanmamış Yüksek Lisans Tezi, Akdeniz Üniversitesi Sosyal Bilimler Enstitüsü, Antalya.

Demir, M., \& Demir, Ş. Ş. (2001). Her Şey Dahil (All-Inclusive) Pansiyon Türü Uygulamasının Konaklama İşletmeleri, Personel, Müşteriler, Seyahat Acentaları ve Bölgedeki Diğer İşletmeler Açısından Olumlu ve Olumsuz Yönlerinin Analizi. Maltepe Üniversitesi Turizm Araştırmaları Dergisi, 1(1), 67-100.

Gökdeniz, A., Oya, A. S., \& Tamer, B. (2000). Her Şey Dahil Pansiyon Türünün (All Inclusive) Turizm Sektöründeki İşletmeler Açısından Analizi ve Örnek Bir Uygulama, 1. Ulusal Türkiye Turizmi Sempozyumu Tebliğ Kitapçığı, İzmir: Türkiye Turizmini Araştırma Enstitüsü, ss. 290-301.

Gülbahar, M. O. (2002). Turizmde Her Şey Dahil (All-Inclusive) Tur Satış Uygulamalarının Değerlendirilmesi, Yayınlanmamış Yüksek Lisans Tezi, İstanbul Üniversitesi Sosyal Bilimler Enstitüsü, İstanbul.

Gürkan, T. A. (2002). Her Şey Dahil (All Inclusive) Sisteminin Türk Turizmi Açısından İncelenmesi (Antalya-Kemer Örneği), Yayınlanmamış Yüksek Lisans Tezi, Sakarya Üniversitesi Sosyal Bilimler Enstitüsü, Sakarya.

Heung, V. C. S., \& Chu, R. (2000). Important Factors Affecting Hong Kong Consumers Choice of a Travel Agency for All-Inclusive Package Tours. Journal of Travel Research, 39, 52-59.

Issa, J. J., \& Jayawardena, C. (2003). The All-Inclusive Concept in the Caribbean. International Journal of Contemporary Hospitality Management, 15(3), 167-171.

Johnson, K. (2011). Is the Increase in All Inclusive Really A Blow to Sustainable Tourism? http://blog.beatthebrochure.com/is-the-increase-in-all-inclusive-really-a-blow-tosustainable-tourism/120. (30.10.2018).

Menekşe, R. (2005). Her Şey Dahil Sisteminin ve Sistemden Faydalananlar Açısından Etkilerinin Otel Yöneticilerinin Gözünden Değerlendirilmesi (Marmaris Örneği). Ekonomik ve Sosyal Araştırmalar Dergisi, 1, 97-124.

Otar, H. (2008). Konaklama İşletmelerinde Uygulanan Her Şey Dahil Sisteminin İşgörenlerin İş Tatmini Üzerindeki Etkisi. Yüksek Lisans Tezi, Gazi Üniversitesi Eğitim Bilimleri Enstitüsü, Ankara.

Özdemir, B. (2001). Otel İşletmelerinde Mutfak Yönetimi ve Her Şey Dahil (AllInclusive) Uygulamasının Mutfak Yönetimine Etkileri Üzerine Sektörel Bir Araştırma. Yayınlanmamış Yüksek Lisans Tezi, Akdeniz Üniversitesi Sosyal Bilimler Enstitüsü, Antalya.

Özdemir, A., Işık, S., Çizel, R. B., \& Aykın, S. M. (2011). Effects of the All-Inclusive System (AIS) on the Financial Structure of Accommodation Enterprises in Antalya. European Journal of Social Sciences, 24 (4), 503-515. 
Responsible Travel (2013). 2013 World Responsible Tourism Awards. https://www.responsibletravel.com/holidays/responsible-tourism/travelguide/2013-awards-winners. (05.06.2018)

Resort Turizm ve Seyahat Dergisi (2004). Herşey Dahil, Yurtiçi Pazarda da Hakim Konaklama Biçimi Oldu, 16.

Süklüm, N. (2006). Türkiye'de Hizmet Sektöründeki Turizm İşletmelerinde Uygulanan "Herșey Dahil" Sisteminin Müşteri Memnuniyeti Üzerindeki Etkisinin Ölçümlenmesi ve Bir Alan Araştırması. Yayınlanmamış Yüksek Lisans Tezi, Adnan Menderes Üniversitesi Sosyal Bilimler Enstitüsü, Aydın.

Terzioğlu, M., \& Gökovali, U. (2016). Economic Linkages and Leakages in the Hotel Industry: The First Empirical Evidence from Turkey. Tourism Economics, 22 (4), 715-728.

Tourism Concern (2012). All-Inclusive Holidays-Excluding Local People in Tourist

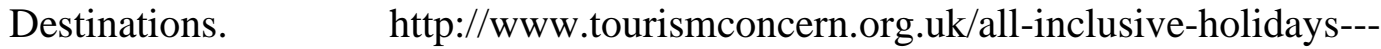
excluding-local-people.html. (30.10.2018).

Tuncer, A. (1997). Seyahat Acentalarının Konaklama İşletmeleri ile Entegrasyonunun Paket Tur Satışlarına Etkisi. Gazi Üniversitesi Sosyal Bilimler Enstitüsü, Ankara.

UNEPTIE (2007). Economic Impacts of Tourism. http://www.uneptie.org/pc/tourism/sust-tourism/economic.htm. (27.09. 2018).

Üner, M. M., Sökmen, A., \& Birkan, İ. (2006). Her Şey Dahil Uygulamasının Konaklama işletmeleri Üzerine Etkisi: Antalya Örneği. Anatolia: Turizm Araştırmaları Dergisi, 17 (1), 35-50.

Üngüren, E., Algür, S., \& Doğan, H. (2009). Konaklama ve Seyahat Acentaları Yöneticilerinin Her Şey Dahil Sistemine Yönelik Tutumları: Antalya Örneği. Karamanoğlu Mehmetbey Üniversitesi Sosyal ve Ekonomik Araştırmalar Dergisi, (2), 95-112.

Üngüren, E., \& Cengiz, F. (2009). Her Şey Dahil Sisteminin Pazarlama Karmas1 Unsurları Kapsamında Değerlendirilmesi. 3. Ulusal Gastronomi Sempozyumu ve Sanatsal Etkinlikler, 17-18 Nisan 2009, Antalya.

Yayl1, A., \& Yayla, İ. (2012). Reasons of Tourists' Preference of All-Inclusive System. İşletme Araştırmaları Dergisi, 4 (1), 143-167.

Yurtseven, İ. (2004). Herşey Dahil Sistemi için Standart Oluşturulmas1, http://www.turizmgazetesi.com/articles/article.aspx?id=3, (05.06.2018).

Yürik, E. Ö. (2002). Herşey Dahil (All Inclusive) Sistemin Türk Turizm Sektörüne Etkileri, T.C. Turizm Bakanlığı, II. Turizm Şurası Bildirileri, Cilt: 1, 12-14 Nisan, Ankara. 